\title{
Photosynthetic enhancement and diurnal stem and soil carbon fluxes in a mature Norway spruce stand under elevated $\mathrm{CO}_{2}$
}

\author{
Martin Karl-Friedrich Bader ${ }^{1 *}$, Manuel Mildner ${ }^{2}$, Christina Baumann $^{2}$, Sebastian Leuzinger ${ }^{3}$, \\ Christian Körner \\ ${ }^{1}$ New Zealand Forest Research Institute (SCION), Te Papa Tipu Innovation Park, 49 Sala \\ Street, 3046 Rotorua, New Zealand \\ ${ }^{2}$ Institute of Botany, University of Basel, Schönbeinstrasse 6, 4056 Basel, Switzerland \\ ${ }^{3}$ Institute for Applied Ecology New Zealand, School of Applied Sciences, Auckland University \\ of Technology, 31-33 Symonds Street, Auckland 1142, New Zealand
}

* Corresponding author

To be submitted to Environmental and Experimental Botany

Type of article: Regular paper

Author Contributions: MKFB, SL, MM and CK conceived and designed the experiments. CB, MM, MKFB and SL performed the measurements and analysed the data. MKFB and MM wrote the manuscript, and CK and SL provided input and comments.

Keywords: global change, carbon assimilation, stem respiration, soil respiration, free-air $\mathrm{CO}_{2}$ enrichment (FACE), ecosystem carbon cycling

\begin{abstract}
Understanding the effects of elevated atmospheric $\mathrm{CO}_{2}$ on carbon (C) relations of mature forest trees is central to understanding ecosystem $\mathrm{C}$ fluxes and pools in a future high- $\mathrm{CO}_{2}$ world. Here, we investigated the $\mathrm{CO}_{2}$-induced photosynthetic enhancement and the diurnal variation in shoot carbon assimilation, stem $\mathrm{CO}_{2}$ efflux and soil respiration associated with ca. 110-year-old and $37 \mathrm{~m}$ tall Norway spruce trees (Picea abies (L.) H.Karst.) growing under free air $\mathrm{CO}_{2}$ enrichment (FACE; $e \mathrm{CO}_{2}$ ) in a mixed, near-natural forest in Northern Switzerland. Diurnal measurements of these major $C$ fluxes were conducted simultaneously on three occasions: one week before and after the start of $\mathrm{CO}_{2}$ enrichment, and one year later. Under controlled leaf chamber conditions, an increase in the atmospheric $\mathrm{CO}_{2}$ concentration of $c a .150 \mathrm{ppm}$ above ambient stimulated light-saturated rates of photosynthesis in previous- and current-year upper-canopy shoots equally by $73 \pm 2 \%$. In the course of the day such large differences in $\mathrm{C}$ assimilation between $e \mathrm{CO}_{2}$ and $a \mathrm{CO}_{2}$ trees only occurred around midday under non-limiting light conditions. The $\mathrm{CO}_{2}$ efflux rates from spruce stems $\left(C E_{\text {stem }}\right)$ and surrounding soil $\left(R_{\text {soil }}\right)$ shared a similar range during night- and
\end{abstract}


daytime (3-5 $\left.\mu \mathrm{mol} \mathrm{m} \mathrm{m}^{-2} \mathrm{~s}^{-1}\right)$ but were not stimulated by $e \mathrm{CO}_{2}$. Both $C E_{\text {stem }}$ stem and $R_{\text {soil }}$ were still rising when photosynthesis approached evening light compensation potentially reflecting the time lag in assimilate allocation to stem tissue and fine roots. Our findings suggest a strong photosynthetic enhancement during the initial $\mathrm{CO}_{2}$ enrichment phase but provide no evidence for an overall or daytime-dependent stimulation of respiratory $\mathrm{CO}_{2}$ fluxes indicating that the extra $C$ was not quickly returned to the atmosphere through respiratory processes in spruce stems or surrounding soil.

\section{Introduction}

Besides unwanted effects of elevated atmospheric $\mathrm{CO}_{2}$ on climatic forcing (climate warming), a $\mathrm{CO}_{2}$ enriched atmosphere is often considered a potential 'fertilizer' of plant growth, given the rate-limiting role of ambient $\mathrm{CO}_{2}$ concentrations for leaf photosynthesis. However, whether such a $\mathrm{CO}_{2}$-driven stimulation of tree growth will occur is highly questionable, because of the many other constraints of growth, mineral nutrients in particular (Körner 2006). A stimulation of growth by elevated $\mathrm{CO}_{2}$ requires a net carbon (C) gain, that is a positive difference between carbon uptake and loss.

Photosynthetic $C$ uptake represents the largest flux in the global $C$ cycle followed by the respiratory $C$ release from ecosystems to the atmosphere (Roy et al. 2001). Soil respiration $\left(R_{\text {soil }}\right)$ comprises the total $\mathrm{CO}_{2}$ released from auto- and heterotrophic processes in soils, and may account for up to $80 \%$ of the $\mathrm{CO}_{2}$ emissions in temperate conifer and hardwood forests (Wofsy et al. 1993, Malhi et al. 1999, Janssens et al. 2001). A further important pathway for assimilated $\mathrm{CO}_{2}$ is stem efflux $\left(C E_{\text {stem }}\right)$, a combination of $\mathrm{CO}_{2}$ respired by local woody tissue and respiratory $\mathrm{CO}_{2}$ originating from elsewhere in the plant-soil system, part of which dissolves in xylem sap and is transported in the transpiration stream (Teskey \& McGuire 2005, 2007, Etzold et al. 2013). In temperate forests, $\mathrm{CO}_{2}$ release from stems may contribute up to $21 \%$ to total ecosystem respiration (Wang et al. 2010). The remaining possible pathways for $\mathrm{C}$ out of an ecosystem (leaching of dissolved organic and inorganic $\mathrm{C}$, emissions of volatile organic and inorganic $\mathrm{C}$ ) are of much less importance and very difficult to measure in mature ecosystems (Schleppi et al. 2012). Any attempt at quantifying a potential ecosystem net carbon gain under elevated $\mathrm{CO}_{2}$, requires data for the main $\mathrm{C}$ fluxes such as leaf photosynthesis, $R_{\text {soil }}$ and $C E_{\text {stem }}$.

Free air carbon dioxide enrichment (FACE) experiments are currently the only available tool to experimentally investigate future changes in $\mathrm{C}$ pools and fluxes in mature forests. Multiyear FACE experiments in forests have shown that photosynthetic $\mathrm{C}$ uptake at the leaf-level is about $40-60 \%$ enhanced under elevated $\mathrm{CO}_{2}$ depending on the magnitude of atmospheric $\mathrm{CO}_{2}$-enrichment and plant species (Nowak et al. 2004; Bader et al. 2010; Ellsworth et al. 2012; Norby \& Zak 2011). This stimulation appears to be persistent in many species, although cases of partial or complete photosynthetic downregulation over time have also been reported (Ellsworth et al. 2012, Norby \& Zak 2011). However, no relative growth stimulation of a magnitude equivalent to the photosynthetic stimulation has ever been observed in any of the studies and in systems that had reached steady state canopy density and root tunover, no sustained stimulation had been found unless mineral fertilizer was applied (e.g. Norby \& Zak 2011; Bader et al. 2013; Sigurdsson et al. 2013), leaving the question of the fate of the extra $C$ assimilated through photosynthesis. Given the time 
required for $\mathrm{C}$ sink limitation to come into play, one might expect stronger $\mathrm{CO}_{2}$ 'fertilization' effects early after an experimental step increase in the atmospheric $\mathrm{CO}_{2}$ concentration compared to a long-term effect (Leuzinger et al. 2011). Here we explore the initial carbon relations of mature spruce trees to an abrupt $150 \mathrm{ppm}$ rise in canopy level $\mathrm{CO}_{2}$ concentration.

One plausible pathway for the extra $C$ taken up by forests exposed to elevated atmospheric $\mathrm{CO}_{2}$ concentrations is increased soil respiration. However, the stimulation of belowground $\mathrm{C}$ transfer under $e \mathrm{CO}_{2}$ in a Pinus taeda stand has only resulted in a modest increase in soil respiration (Jackson et al. 2009). In general, young, expanding stands showed greater enhancement of soil $\mathrm{CO}_{2}$ efflux $(23-54 \%)$ than more mature stands $(12-16 \%)$ under $e \mathrm{CO}_{2}$ (King et al. 2004). Long-term trends under $\mathrm{CO}_{2}$ enrichment have been inconclusive because rates of $\mathrm{CO}_{2}$ efflux from forest soils have been shown to decline over time at the Oak Ridge National Laboratory FACE site (ORNL-FACE), increase over time at the Duke University FACE site (Duke-FACE), remained largely unaffected at the Swiss Canopy Crane FACE site (SCCFACE) site under deciduous trees, and tended to decline under spruce (King et al. 2004, Jackson et al. 2009, Bader \& Körner 2010, Mildner et al. 2015). $R_{\text {soil }}$ may be indirectly influenced by elevated $\mathrm{CO}_{2}$ through changes in temperature and soil moisture sensitivity, which may even result in reduced rates of $R_{\text {soil }}$ under $\mathrm{CO}_{2}$ enrichment (Dielemann et al. 2012).

Temporal changes in soil respiration are ultimately driven by net ecosystem productivity unless there is long-term C accumulation such as in peatland (Raich and Nadelhoffer 1989, Caprez et al. 2012). On a seasonal basis, $R_{\text {soil }}$ is largely controlled by climatic drivers (temperature and soil moisture; Tang et al. 2005; Mildner et al. 2015), while C supply from canopy photosynthesis plays a secondary role on this temporal scale (Högberg et al. 2001; Kuzyakov \& Cheng 2001). Diurnal variation in $R_{\text {soil }}$ is typically low (Buchmann 2000; Bader \& Körner 2010), and dominated by photosynthesis, with $R_{\text {soil }}$ lagging behind by several hours to days (Tang et al. 2005; Wertin \& Teskey 2008; Kuzyakov \& Gavrichkova 2010; Epron et al. 2011). In closed-canopy forests, diurnal soil temperature and moisture show little variation on rainless days and thus have only minor effects on daily $R_{\text {soil }}$ (Tang et al. 2005; Bader \& Körner 2010).

Although woody tissue respiration can consume $11-33 \%$ of the total C assimilated by coniferous trees (Ryan et al. 1995), this respiratory component of the forest $C$ budget is rarely quantified. Generally, $\mathrm{CO}_{2}$ efflux from stems $\left(C E_{\text {stem }}\right)$ can be divided into a growth and a maintenance component, and a third component related to ion uptake (Amthor 1984). The effects of elevated $\mathrm{CO}_{2}$ on $C E_{\text {stem }}$ are unclear, as both increases but also reductions have been observed (Carey et al. 1996; Edwards et al. 2002; Gielen et al. 2003; Zha et al. 2005). $C E_{\text {stem }}$ and sap flow were found to be either positively (Levy et al. 1999), or negatively correlated (Bowman et al. 2005; Teskey \& McGuire 2007), reflecting the transport of dissolved $\mathrm{CO}_{2}$ in or out of the stem compartment via the xylem stream (Levy et al. 1999; Teskey \& McGuire 2002; Moore et al. 2008; Bloemen et al. 2013, Etzold et al. 2013). Therefore, any changes in sap flow under $e \mathrm{CO}_{2}$ relative to ambient conditions might also alter the rate of $C E_{\text {stem. }}$. $A$ strong correlation between $C E_{\text {stem }}$ and wood growth has been observed (Ryan et al. 1994). Seasonal variations in $C E_{\text {stem }}$ are primarily driven by 
temperature, but tree phenology, stem-internal $\mathrm{CO}_{2}$ concentration, and the contribution of xylem-transported $\mathrm{CO}_{2}$ also produce sizable effects (Teskey \& McGuire 2002; 2007; Cernusak et al. 2006; Etzold et al. 2013). However on a diurnal time scale, temperature seems to have a stronger impact on $C E_{\text {stem }}$ than any other factor (Damesin et al. 2002).

In the present study, mature (ca. 110-year-old and $37 \mathrm{~m}$ tall) Picea abies trees growing in a near-natural forest in northwest Switzerland were subjected to elevated $\mathrm{CO}_{2}$ concentrations by means of free air $\mathrm{CO}_{2}$ enrichment (FACE) technology. We aimed to characterise the main $\mathrm{CO}_{2}$ fluxes (photosynthetic $\mathrm{C}$ uptake, $R_{\text {soil }}$ and $C E_{\text {stem }}$ ) under elevated $\mathrm{CO}_{2}$ compared to current ambient $\mathrm{CO}_{2}$ levels on an intra-daily timescale. This was achieved by simultaneously measuring net photosynthetic rates in branchlets using a crane gondola, and respiratory $\mathrm{CO}_{2}$ release from stems and the soil in the understorey of $P$. abies trees before and after the onset of free air $\mathrm{CO}_{2}$ enrichment. From current knowledge, we expected a stimulation of shoot net photosynthesis, but also enhanced $\mathrm{C}$ recycling to offset likely sink limitation of growth in such a natural forest setting.

\section{Material and methods}

Study site and $\mathrm{CO}_{2}$ enrichment system

This free air $\mathrm{CO}_{2}$ enrichment (FACE) study was conducted in a ca. 110-120 year-old, nearnatural mixed forest, located $12 \mathrm{~km}$ southwest of Basel, Switzerland $\left(47^{\circ} 33^{\prime} \mathrm{N}, 7^{\circ} 36^{\prime} \mathrm{E}, 500\right.$ $\mathrm{m}$ a.s.l). The species-rich stand is dominated by hardwood and conifer trees (Fagus sylvatica L., Quercus petraea (Matt.) Liebl., Carpinus betulus L., Picea abies (L.) Karst., Larix decidua Mill., Pinus sylvestris L., Abies alba Mill.). In forest patch selected for the $\mathrm{CO}_{2}$ enrichment experiment Picea abies is the predominant tree species. The mild temperate climate in this region is characterised by a mean growing season temperature of $14.7{ }^{\circ} \mathrm{C}$ (May September) and around $1000 \mathrm{~mm}$ annual precipitation (Bader \& Körner 2010). In 2009, five ca. 110-year-old Picea abies trees of around $37 \mathrm{~m}$ height were fitted with a modified webFACE system (Pepin \& Körner 2002, Mildner et al. 2014) using a construction crane. In brief, the computer-controlled release of pure $\mathrm{CO}_{2}$ occurred through a fine web of perforated lightweight tubing fixed around tree branches. The target concentration of $\mathrm{CO}_{2}$ was 550 ppm and an air sampling system comprising multiple sampling points per tree was used to monitor canopy $\mathrm{CO}_{2}$ concentration using infrared gas analysis. $\mathrm{CO}_{2}$-enrichment was confined to the tree crowns between 15 and $37 \mathrm{~m}$ above ground and suspended when temperature dropped below $4{ }^{\circ} \mathrm{C}$, light intensity above the canopy was $<100 \mu \mathrm{mol} \mathrm{m} \mathrm{m}^{-2} \mathrm{~s}^{-1}$ or when wind speed exceeded $10 \mathrm{~m} \mathrm{~s}^{-1}$. The $\mathrm{CO}_{2}$ control and monitoring system scanned across four sectors within each tree crown to ensure adequate $\mathrm{CO}_{2}$ distribution and to maintain the target $\mathrm{CO}_{2}$ level as closely as possible even under changing wind conditions. The uppermost two meters of a crown formed the top sector followed by three $120^{\circ}$ sectors equally subdividing the remainder of the crown. From 2009 to 2011 the canopy $\mathrm{CO}_{2}$ concentration averaged $541 \mathrm{ppm}, 532 \mathrm{ppm}$, and $541 \mathrm{pm}$, respectively; and the median $\mathrm{CO}_{2}$ concentrations ranged from 500 to $560 \mathrm{ppm}$ (Mildner et al. 2014). Five spruce trees of similar age and height growing at sufficient distance from the $\mathrm{CO}_{2}$-treated trees served as controls (for tree map see: http://static-content.springer.com/esm/art\%3A10.1007\%2Fs10533-015-00845/MediaObjects/10533_2015_84_MOESM4_ESM.pdf). 
Stability of gas-exchange measurements after branchlet removal

Since four out of the five control trees were located beyond the reach of the canopy crane, we relied on tree climbers for sample collection from the crowns of these trees. To evaluate the suitability of this approach, we monitored the stability of photosynthetic gas-exchange measurements over time following branchlet removal from a set of spruce trees that were accessible with the crane gondola: a terminal south-facing branchlet from the outer spruce crown was enclosed in the leaf chamber of the photosynthesis system and gas-exchange measurements were started in logging mode using a 1-min measurement interval. Then, the enclosed branchlet was severed and the photosynthesis system including the detached sample was transferred to the field laboratory on site where logging continued over a period of 230 minutes under saturating light conditions of $1500 \mu \mathrm{mol} \mathrm{m} \mathrm{m}^{-2} \mathrm{~s}^{-1}$ provided by a cold light source (Schott, KL 1500, Mainz, Germany), $25{ }^{\circ} \mathrm{C}$ leaf temperature and an air-toleaf vapour pressure deficit of around $1.1 \mathrm{kPa}$. This procedure was replicated five times on sunny days using sun-exposed branchlets from five different spruce trees.

Photosynthetic enhancement ratio, $A / C_{i}$ curves, diurnal measurements of photosynthesis, stem and soil $\mathrm{CO}_{2}$ efflux

We performed three diurnal measurement campaigns on sunny, cloudless days before, during the first week, and one year after the start of canopy $\mathrm{CO}_{2}$ enrichment on 30 July 2009 (measurement dates: 29 July 2009, 06 August 2009, 14 July 2010). We simultaneously measured net rates of photosynthesis, stem $\mathrm{CO}_{2}$ efflux $\left(C E_{\text {stem }}\right)$ and soil respiration $\left(R_{\text {soil }}\right)$ at five times throughout the day from 3 am to 5 pm (except for $C E_{\text {stem }}$ on 14 July 2010 when only four measurements were conducted). For each of the daily measurement times, gasexchange was recorded on previous- and current-year needles in the north- and southfacing parts of the crown (except for 14 July 2010 where only south-facing shoots were measured); two $C E_{\text {stem }}$ measurements were taken on the north- and south-facing side of stems and three $R_{\text {soil }}$ records per tree were taken and averaged. Stomatal conductance data and water relations of these diurnal campaigns have already been published elsewhere (Leuzinger \& Bader 2012).

Instantaneous rates of shoot gas-exchange were recorded using a portable photosynthesis system equipped with a conifer chamber (LI-6400 XT, chamber 6400-05, Licor, Lincoln, NE, USA). During the pre-treatment campaign, all samples were measured at $385 \mathrm{ppm}$ leaf chamber $\mathrm{CO}_{2}$ concentration. After the start of $\mathrm{CO}_{2}$ enrichment, shoots of control trees were measured at $385 \mathrm{ppm}$ and those of trees exposed to elevated $\mathrm{CO}_{2}$ at $550 \mathrm{ppm}$ leaf chamber $\mathrm{CO}_{2}$ concentration. The photosynthetic enhancement ratio was assessed as the needleintrinsic ratio of light-saturated photosynthesis under $550 \mathrm{ppm}$ over $385 \mathrm{ppm}$ chamber $\mathrm{CO}_{2}$ concentration $\left(A_{550} / A_{385}\right)$, i.e. all samples were measured at both 385 and $550 \mathrm{ppm}$ chamber $\mathrm{CO}_{2}$ concentration. $A / C_{\mathrm{i}}$ curves were performed on detached shoots at ambient relative humidity and the chamber temperature set to $25^{\circ} \mathrm{C}$ which closely matched the ambient air temperature at that time. Saturating light levels of $1600 \mu \mathrm{mol} \mathrm{m}^{-2} \mathrm{~s}^{-1}$ were provided by a halogen light source (Transtector F-800, AIP WILD AG Zürich, Switzerland), mounted above the conifer chamber. The $A / C_{\mathrm{i}}$ curve procedure started at $385 \mathrm{ppm}$ chamber $\mathrm{CO}_{2}$ 
concentration, before this was stepwise reduced to 300, 200, 100, and $50 \mathrm{ppm}$. Thereafter, chamber $\mathrm{CO}_{2}$ was reset to $385 \mathrm{ppm}$ to check whether (partial) Rubisco deactivation had occurred. If the original photosynthetic rate could not be restored the recording was terminated and started over with a new sample. From $385 \mathrm{ppm}$ the chamber $\mathrm{CO}_{2}$ concentration was increased to $600,800,1000,1500$ and $2000 \mathrm{ppm}$. The analyser cells of the gas-exchange system were matched after each change in chamber $\mathrm{CO}_{2}$ concentration. Individual response curves were typically completed within $35 \mathrm{~min}$. We used a Farqhar-type photosynthesis model to derive the maximum rate of carboxylation $\left(V_{c \max }\right)$ and maximum electron transport rate $\left(J_{\max }\right)$ from the $A / C_{\mathrm{i}}$ recordings (Long \& Bernacchi 2003).

We marked the section of the sample branchlets that was enclosed by the conifer chamber and collected the needles after the completion of the recordings. The projected needle area was determined using WinSEEDLE analysis software (Regent Instruments Inc., Quebec, Canada).

Instantaneous rates of $C E_{\text {stem }}$ were measured using a portable soil respiration system (LI$6400 \mathrm{XT}$, soil $\mathrm{CO}_{2}$ flux chamber 6400-09, Licor, Lincoln, NE, USA). The soil respiration chamber was horizontally oriented and strapped on PVC rings (10 $\mathrm{cm}$ diameter) glued onto the bark (loose bits removed) at $1.3 \mathrm{~m}$ height using silicone sealant. Since all trees had DBH values greater than $45 \mathrm{~cm}\left(a \mathrm{CO}_{2}: 46-57 \mathrm{~cm}, e \mathrm{CO}_{2}: 48-64 \mathrm{~cm}\right)$ the surface area enclosed by the rings was virtually flat making curvature corrections redundant. Every recording comprised three measurement cycles each consisting of a passive $\mathrm{CO}_{2}$ increase in the chamber headspace followed by a $\mathrm{CO}_{2}$ scrubbing back to ambient $\mathrm{CO}_{2}$ concentrations of 385 ppm.

Instantaneous rates of soil respiration were recorded using two identical custom-made static chambers fitted with diffusion-aspirated nondispersive infrared gas analysers (IRGAs) and relative humidity/temperature sensors (GMP343 carbon dioxide probe, HMP75 rH/T probe, Vaisala, Vantaa, Finland). The chamber design and technical details are described in Bader \& Körner (2010). During measurements, the chambers were placed on polypropylene rings ( $5 \mathrm{~cm}$ in height and $20 \mathrm{~cm}$ in diameter) inserted $2 \mathrm{~cm}$ into the forest soil. Individual recordings of soil $R_{\text {soil }}$ lasted 5 min with a $5 \mathrm{~s}$ reading interval. Rates of $R_{\text {soil }}$ were calculated from the slope of a linear regression applied to the initial $\mathrm{CO}_{2}$ increase within the chamber. The first minute of the recordings was omitted from the regression analysis to avoid small flux disturbances involved with chamber placement. Under identical experimental conditions, Heinemeyer \& McNamara (2011) showed that using short sampling times with closed static chambers yields flux estimates that are comparable to the fluxes measured with a LICOR 8100 closed dynamic chamber reference system (LICOR, Lincoln, NE, USA).

\section{Statistical analysis}

All statistical computations were performed using the statistical analysis and graphics software $R$ version 3.1.0 ( $R$ development Core Team 2014). The stability of photosynthetic gas-exchange measurements of detached branchlets was modelled using an ordinary least squares model. $A / C_{i}$ curves recorded under pre-treatment and FACE conditions were analysed using Farquhar-type equations (Long \& Bernacchi, 2003) fitted by generalised nonlinear least squares ( $\mathrm{gh} / \mathrm{s}$ ). Model diagnostic plots suggested heteroscedasticity, which was modelled by incorporating exponential or power variance functions using $C_{i}$ as variance covariate. In order to compare $a \mathrm{CO}_{2}$ vs. $e \mathrm{CO}_{2}$ we formulated parameter models allowing 
separate parameter estimates for each $\mathrm{CO}_{2}$ treatment. These parameter models were then compared to a base model (assuming common parameter estimates for both $\mathrm{CO}_{2}$ treatments) using likelihood ratio tests.

The photosynthetic enhancement ratios $\left(A_{550} / A_{385}\right)$ prior and during FACE were analysed using generalised least squares models ( $g / s, \mathrm{R}$ package $n / m e$, Pinheiro et al. 2014). These models contained cardinal direction, needle age, $\mathrm{CO}_{2}$ treatment and their interaction as fixed term. Model diagnostic plots suggested heteroscedasticity in the pre-treatment and the treatment data, which was modelled by incorporating exponential or power variance functions using the fitted values as variance covariate.

Generalised additive mixed models (GAMMs) were applied to the non-aggregated data to analyse the diurnal courses of needle gas-exchange, stem and soil respiration (Wood, 2011, $\mathrm{R}$ package $\mathrm{mgcv}$ ). The GAMMs for photosynthetic gas-exchange contained ' $\mathrm{CO}_{2}$ treatment', 'needle age' and 'date' (date of diurnal recording) as factors and a smoothing term for 'time of day' (thin plate regression spline). The GAMMs for the stem and soil respiration data contained ' $\mathrm{CO}_{2}$ treatment' and 'date' as factors and smoothers for 'time of day' and 'temperature' (bark or soil temperature).

'Tree individual' nested in 'date' were incorporated as random effects in all models to account for the repeated measures. Serial autocorrelation was modelled using an autocorrelation structure of order 1 (corAR1, Pinheiro et al. 2014, R package nlme). To test whether the diurnal course followed a common pattern across $\mathrm{CO}_{2}$ treatments $\left(\mathrm{CO}_{2} \times\right.$ time of day interaction), a model with one common smoother was compared to a model allowing separate smoothers for $a \mathrm{CO}_{2}$ and $e \mathrm{CO}_{2}$. The same approach was used to test the date $\times$ time of day interaction. Model comparisons were based on the Akaike Information Criterion (AIC), which measures goodness of fit and model complexity and is more robust than likelihood ratio tests when comparing GAMMs (Zuur et al. 2009). The lower the AIC the better the model fit. The difference in AIC between two candidate models is called $\triangle A I C$ and models are considered different if the $\triangle \mathrm{AIC}$ is greater than 10 (Burnham \& Anderson 2002). Graphical model validation tools (residual plots for variance homogeneity and quantilequantile plots for normality) were used to assess the underlying model assumptions. The residual plots indicated heteroscedasticity, which was modeled using a power variance structure (varPower, R package $n$ lme).

\section{Results}

\section{Stability of photosynthetic rates after branchlet removal}

In situ measurements of net photosynthesis of one-year old branchlets showed an average net photosynthetic rate of $7 \pm 0.4 \mu \mathrm{mol} \mathrm{m}^{-2} \mathrm{~s}^{-1}$ (mean $\pm \mathrm{SE}, n=5$, Fig. 1). After branch detachment, photosynthesis declined at a rate of less than $2 \%$ per hour. Nearly 4 hours after branchlet detachment the photosynthetic rate had only dropped by $0.5 \mu \mathrm{mol} \mathrm{m} \mathrm{m}^{-2} \mathrm{~s}^{-1}$. Stomatal conductance showed only minor changes in the first $45 \mathrm{~min}$ after branchlet removal but had increased by $22 \%$ at the end of the recording ( $230 \mathrm{~min}$ after detachment). 
Photosynthetic enhancement, $V_{\mathrm{cmax}}$ and $J_{\max }$

The photosynthetic enhancement ratio was remarkably similar across designated $a \mathrm{CO}_{2}$ and $e \mathrm{CO}_{2}$ trees, needle age and cardinal directions averaging $1.69 \pm 0.02$ (mean $\pm \mathrm{SE}$ ) prior to the onset of $\mathrm{CO}_{2}$ enrichment and $1.76 \pm 0.04$ shortly afterwards (Fig. 2, Table 1).

Similarly, $V_{\text {cmax }}$ and $J_{\max }$ showed no statistically significant differences between needle age and designated $a \mathrm{CO}_{2}$ and $e \mathrm{CO}_{2}$ trees, apart from the significantly higher $V_{\text {cmax }}$ seen in current-year needles of control trees before the start of $\mathrm{CO}_{2}$ enrichment (Fig. 3). Average $V_{c \max }$ values were in the range of $23-36 \mu \mathrm{mol} \mathrm{m}^{-2} \mathrm{~s}^{-1}$ and $J_{\max }$ varied between 95 and 120 $\mu \mathrm{mol} \mathrm{m} \mathrm{m}^{-2}$ (Fig. 3).

\section{Diurnal C fluxes}

Photosynthetic gas-exchange showed a typical daily pattern with a rapid rise in the early morning hours to maximum light-saturated values before noon $\left(a \mathrm{CO}_{2}: 6-9 \mu \mathrm{mol} \mathrm{m} \mathrm{m}^{-2} \mathrm{~s}^{-1}\right.$, $e \mathrm{CO}_{2}: 9-12 \mu \mathrm{mol} \mathrm{m} \mathrm{m}^{-2} \mathrm{~s}^{-1}$ ), followed by a nearly linear decline over the course of the afternoon (Fig. $4 \mathrm{a}-$ b). Rates of nighttime shoot respiration ranged from 1 to $3 \mu \mathrm{mol} \mathrm{m} \mathrm{m}^{-2} \mathrm{~s}^{-1}$.

The diurnal courses of gas-exchange showed similar patterns across recording dates, ( $\triangle \mathrm{AIC}=$ 32 in support of the model with one common smoothing term for all dates) but photosynthetic rates were somewhat higher during the two 2009 recordings compared to 2010 (Table 2). Previous-year and current-year needles shared a similar diurnal pattern ( $\triangle \mathrm{AIC}=18.4$, supporting the model with one common smoothing term for needle age), which was overall slightly lower in current-year needles (Table 2). Prior to the start of the $\mathrm{CO}_{2}$ experiment, daily peak net photosynthetic rates measured at $385 \mathrm{ppm} \mathrm{CO}_{2}$ were on average already between 1.11 (current-year needles) and 1.44 (previous-year needles) times higher in trees selected for $\mathrm{CO}_{2}$ enrichment compared to control trees (Fig. $4 \mathrm{a}-\mathrm{b}$ left panels). According to the photosynthetic responses of branchlets, the start of $\mathrm{CO}_{2}$ enrichment must have resulted in a strong instantaneous enhancement in daily net photosynthetic rates (integrated over the day) of trees exposed to $e \mathrm{CO}_{2}$ compared to trees growing under $a \mathrm{CO}_{2}$. Taking the pre-treatment differences into account, this $\mathrm{CO}_{2}$-driven photosynthetic stimulation almost doubled $\mathrm{C}$ assimilation in previous-year and current-year needles. High $\mathrm{CO}_{2}$ also resulted in a steeper increase to peak photosynthesis values warranting separate fits for $a \mathrm{CO}_{2}$ and $e \mathrm{CO}_{2} \quad(\triangle \mathrm{AIC}=30.8$ in favour of the model allowing separate smoothing terms for $a \mathrm{CO}_{2}$ and $e \mathrm{CO}_{2}$ ). However, one year after the start of $\mathrm{CO}_{2}$ enrichment (summer 2010), the photosynthetic enhancement had declined in previous year needles (1.35-fold higher under $e \mathrm{CO}_{2}$ compared to $a \mathrm{CO}_{2}$ ) and had virtually disappeared in current-year needles, which showed even $6 \%$ less photosynthetic stimulation relative to the pre-treatment difference (Fig. 4).

Generally, $C E_{\text {stem }}$ and $R_{\text {soil }}$ were lowest at night or in the early morning hours and increased by up to $35 \%$ throughout the day (Fig. $4 \mathrm{c}$ and d). Night values of $C E_{\text {stem }}$ varied on average between 2.8 and $3.8 \mu \mathrm{mol} \mathrm{m} \mathrm{m}^{-2} \mathrm{~s}^{-1}$ and nighttime $R_{\text {soil }}$ ranged from 2.4 to $3.7 \mu \mathrm{mol} \mathrm{m} \mathrm{m} \mathrm{s}^{-1}$. Interestingly, the daily rise in $C E_{\text {stem }}$ was paralleled by an increase in bark temperature, while the increase in $R_{\text {soil }}$ occurred without a corresponding rise in soil temperature. Consequently, 
$\mathrm{T}_{\text {bark }}$ had a significant effect on stem $C$ release $(L=8.54, d f=2, P=0.01)$ but daily $T_{\text {soil }}$ did not significantly affect soil respiration $(L=2.16, d f=2, P=0.34)$.

The highest stem $\mathrm{CO}_{2}$ release of $5 \mu \mathrm{mol} \mathrm{m} \mathrm{m}^{-2} \mathrm{~s}^{-1}$ was measured in the late afternoon during the diurnal recording in 2010 , when bark temperatures reached $29^{\circ} \mathrm{C}$. However, overall the magnitude and the diurnal pattern of $C E_{\text {stem }}$ were similar between recording dates $(\triangle \mathrm{AIC}=2$ in favour of the model with a common smoother for recording date, Table 3). Regardless of recording date, rates of $C E_{\text {stem }}$ were always slightly lower under ambient compared to elevated $\mathrm{CO}_{2}$, but these differences did not warrant separate fits and the magnitude of the differences was not significant $(\triangle \mathrm{AIC}=3$ supporting the model with a common smoother for $\mathrm{CO}_{2}$ treatment, Table 3).

The daily rise in $R_{\text {soil }}$ showed similar shapes across recording dates ( $\triangle \mathrm{AIC}=6$ supporting the model with a common smoother for recording date) but occurred at a significantly lower level in 2010 (Fig. 4, Table 4). The diurnal increase in $R_{\text {soil }}$ also followed a similar pattern across $\mathrm{CO}_{2}$ treatments ( $\triangle \mathrm{AIC}=3.3$ in support of the model with a common smoother). However, similar to the diurnal gas-exchange data, there was a significant pre-treatment difference with $20 \%$ higher rates of soil respiration under trees selected for $\mathrm{CO}_{2}$ enrichment compared to soil under control trees (i.e. the same daily pattern but an upward shift of the curve under $\mathrm{CO}_{2}$-enriched trees). This pre-treatment difference remained constant after the start of the $\mathrm{CO}_{2}$ enrichment in summer 2009 but had nearly disappeared one year later (on a day when the soil at $10 \mathrm{~cm}$ depth was $4{ }^{\circ} \mathrm{C}$ warmer compared to the previous year; Fig. 4) suggesting a reduction in $R_{\text {soil }}$ under $e \mathrm{CO}_{2}$.

\section{Discussion}

\section{Stability of photosynthetic rates after shoot removal}

Logistic constraints frequently impede in situ measurements, especially when dealing with tall trees. Shooting branches or employing tree climbers to collect samples present alternative approaches but the question lingers whether gas-exchange measurements conducted on detached plant material are truly representative. The use of a construction crane allowed us to carefully investigate this issue by continuously logging shoot photosynthesis starting as in situ measurements in the tree crown initiated from the crane gondola and continuing these recordings for nearly 4 hours following the detachment of the branchlet. This removal experiment demonstrated that photosynthetic rates of Norway spruce branchlets remain remarkably constant for at least an hour after detachment (Fig. 1). By comparison, $g_{\mathrm{s}}$ values only remained reasonably constant for about $45 \mathrm{~min}$ and showed a $22 \%$ increase over time (Fig. 1). Consequently, our findings suggest a 45 min window of opportunity for representative gas-exchange measurements on samples collected by tree climbers, which lies well within the timeframe required to perform an $A / C_{i}$ curve recording.

\section{Photosynthetic stimulation under elevated $\mathrm{CO}_{2}$}

Averaged across cardinal directions, needle ages and $\mathrm{CO}_{2}$ treatment, the photosynthetic enhancement in mature Picea abies trees reached $73 \%$ which is in good agreement with 
the values reported for current-year needles of Pinus taeda (+67 \%) growing under elevated $\mathrm{CO}_{2}$ at the Duke FACE site (Ellswoth et al. 2012). However, in contrast to Picea abies, there were marked differences between needle ages in Pinus taeda with only $40 \%$ photosynthetic enhancement seen in previous-year needles. For Pinus radiata cuttings that had been growing in open-top chambers for five years, Greenep et al. (2003) reported photosynthetic stimulation between 34 and $43 \%$ in young needles and between 26 and $49 \%$ in older needles, depending on the time of year. However, these figures were not given as a photosynthetic enhancement ratio (i.e. $a \mathrm{CO}_{2}$ and $e \mathrm{CO}_{2}$ plants measured at both the low and the high $\mathrm{CO}_{2}$ concentration) but were derived from comparisons between maximal photosynthetic rates at the respective growth $\mathrm{CO}_{2}$ concentration.

$V_{c \max }$ and $J_{\max }$ measured in or study trees were in the range of values observed in Pinus taeda exposed to $+200 \mathrm{ppm}$ atmospheric $\mathrm{CO}_{2}$ concentration (Ellsworth et al. 2012). Greenep et al. (2003) reported similar $V_{\text {cmax }}$ values for Pinus radiata cuttings after five years of growth under elevated $\mathrm{CO}_{2}$ in open-top chambers, however, $J_{\max }$ was substantially lower reaching values between 50 and $70 \mu \mathrm{mol} \mathrm{m}^{-2} \mathrm{~s}^{-1}$.

\section{Diurnal C fluxes}

Estimates of $\mathrm{C}$ fixation and respiration rates are key to productivity and $\mathrm{C}$ budget models and findings from other forest FACE studies and chamber-based $\mathrm{CO}_{2}$ experiments commonly suggest an increase in both assimilatory $C$ uptake and respiratory $C$ release (e.g. Ellsworth et al. 2012, Jackson et al. 2009). Here, we aimed at simultaneously quantifying the major diurnal C fluxes in c. 110-year-old and $37 \mathrm{~m}$ tall Picea abies trees and surrounding soil under $e \mathrm{CO}_{2}$. Peak daily $\mathrm{C}$ assimilation rates in both previous-year and current-year needles were strongly enhanced in trees receiving $e \mathrm{CO}_{2}$ relative to control trees, but one year after the start of $\mathrm{CO}_{2}$ enrichment, the photosynthetic stimulation seemed smaller particularly in current-year needles (Fig. 3). However, shoot gas-exchange measurements conducted under controlled conditions $\left(A_{550} / A_{400}\right)$ in 2014 did not provide evidence for photosynthetic downregulation (Klein et al. 2015, in review). The only other FACE study using a conifer species was conducted at the Duke forest in North Carolina, USA, where Pinus taeda had been subjected to FACE over a period of 10 years and on average the exposure to $e \mathrm{CO}_{2}$ enhanced net photosynthesis by $67 \%$ in current year needles and $37 \%$ in previous year needles (Ellsworth et al. 2012) under ambient atmospheric $\mathrm{CO}_{2}$ concentration $+200 \mathrm{ppm}$. We did not observe $\mathrm{CO}_{2}$-related differences in dark respiration in our Picea trees but Griffin et al. (2004) reported an 1.7-2.7-fold increase in the number of mitochondria in needles of Pinus radiata trees grown under $e \mathrm{CO}_{2}$ in open-top chambers. The largest increase in mitchondria was observed at the tip where it led to significantly increased area-based respiration rates. However, the mid-section and base of the needles showed reduced respiration, resulting in an overall $12 \%$ decline in needle respiration under $e \mathrm{CO}_{2}$ (Griffin et al. 2004).

At our FACE site, $C E_{\text {stem }}$ remained unaffected by $e \mathrm{CO}_{2}$, which is consistent with the findings of Gielen et al. (2003) for three Populus species growing in a short-rotation biomass plantation at the POP-FACE facility in Italy. However, at the ORNL and Duke FACE sites, $\mathrm{CO}_{2}$ enrichment resulted in $33 \%$ and $6 \%$ higher rates of $C E_{\text {stem }}$ in Liquidambar styraciflua and Pinus taeda, respectively, during the early stages of these experiments (Edwards et al. 2002, 
Hamilton et al. 2002). Diurnal recordings on 14-year-old Picea abies trees subjected to $\mathrm{CO}_{2}$ enrichment in open-top chambers also showed moderate increases in $C E_{\text {stem }}$ of up to $16 \%$ over control trees (Acosta et al. 2010). $\mathrm{CO}_{2}$-related changes in sap flow may confound comparative $C E_{\text {stem }}$ readings due to the respiratory $\mathrm{CO}_{2}$ dissolved and transported in the transpiration stream and the amount of this $\mathrm{CO}_{2}$ that remains stores internally. $C E_{\text {stem }}$ has been shown to correlate negatively with sap flux density implying that a $\mathrm{CO}_{2}$-induced reduction in whole-tree transpiration would inevitably result in greater $\mathrm{CO}_{2}$ efflux rates from stems (Bowman et al. 2005). However, such confounding can be ruled out because sap flow in Picea abies remained unaffected by $e \mathrm{CO}_{2}$ at the SCC FACE site (Leuzinger \& Bader 2012). The absence of a $\mathrm{CO}_{2}$ effect on $C E_{\text {stem }}$ in the longer term is corroborated by the lack of a $\mathrm{CO}_{2}$ induced stimulation of stem radial growth, which was assessed with girth tapes at breast height $(1.3 \mathrm{~m})$, crown base (20-25 m) and in the upper canopy (30 m; Klein et al. 2015, in review). Atwell et al. (2003) reported initial stimulation of the basal area increment of young, clonal Pinus radiata trees under $e \mathrm{CO}_{2}$ and high-N conditions in open-top chambers, but not under $e \mathrm{CO}_{2}$ alone. However, this initial response ceased after 1.25 years, resulting in similar relative growth rates across all $e \mathrm{CO}_{2}$ and $\mathrm{N}$ treatment combinations.

Given the initial increase in photosynthetic $\mathrm{C}$ uptake under $e \mathrm{CO}_{2}$ and the close coupling between photosynthesis and $R_{\text {soil }}$ (Tang et al. 2005) we expected a rapid stimulation of soil $\mathrm{CO}_{2}$ efflux. Stable $\mathrm{C}$ isotope tracing revealed a small yet clear signal of the ${ }^{13} \mathrm{C}$ signature of the fossil $\mathrm{CO}_{2}$ used for canopy enrichment in soil air approximately 12 days after the start of this FACE study (Mildner et al. 2014). However, during the first week of $\mathrm{CO}_{2}$ enrichment $R_{\text {soil }}$ remained unaffected and in the 2010 assessment the pre-treatment difference had nearly vanished, suggesting a slight suppression rather than a stimulation of $R_{\text {soil, }}$ which was supported by bi-weekly seasonal measurements revealing a small but significant reduction in $R_{\text {soil }}$ under $\mathrm{CO}_{2}$-enriched trees compared to the controls (Mildner et al. 2015). The lack of a $\mathrm{CO}_{2}$ driven stimulation of $R_{\text {soil }}$ is in contrast to other forest FACE experiments where $R_{\text {soil }}$ commonly increased in response to $\mathrm{COO}_{2}$ under various soil and canopy conditions (King et al. 2004) but it is in line with findings for soil under deciduous trees at the same site (Bader \& Körner 2010) and with the seasonal figures associated with our spruce trees (Mildner et al. 2015; Klein et al. 2015, in review). Though none of the stands in the study by King et al. (2005) had achieved canopy-closure when FACE commenced, their findings suggest that the magnitude of the $\mathrm{CO}_{2}$-driven stimulation of $R_{\text {soil }}$ strongly depends on stand age as greater responses were reported for very young compared to more advanced stands. This may be largely related to the contribution of root respiration to the overall $R_{\text {soil }}$ signal. The SCC site is a mature, closed-canopy stand with trees aged well over 100 years suggesting fully expanded root systems ('root closure'), that one would expect to respond less vigorously to $\mathrm{CO}_{2}$-enrichment (Mildner et al. 2015) than expanding root systems in expanding stands as was initially the case at the Duke- and ORNL-FACE sites. Moreover, soil nutrient availability is likely to play a role. At the Duke Forest FACE site, fertiliser addition resulted in reductions in $R_{\text {soil }}$ under both $a \mathrm{CO}_{2}$ and $e \mathrm{CO}_{2}$, suggesting that forests on high-fertility sites, such as ours (20- $25 \mathrm{~kg} \mathrm{~N} \mathrm{ha}^{-1} \mathrm{a}^{-1}$ wet nitrogen deposition, Thimonier et al. 2010), respire less $\mathrm{CO}_{2}$ back to atmosphere (Butnor et al. 2003).

A noticeable feature of the diurnal courses was the continuing rise in $C E_{\text {stem }}$ stem and $R_{\text {soil }}$ towards the evening, when shoot photosynthesis was already approaching evening light compensation. We speculate that this may reflect a time lag in assimilate allocation to stem tissue and fine roots, however, published findings about the effect of carbohydrates on 
respiratory processes are mixed and thus there is no unanimous conclusion on this topic (Covey-Crump et al. 2002; Atkin et al. 2000).

For logistic reasons, step-changes in $\mathrm{CO}_{2}$ concentrations are common in FACE experiments, however, in reality atmospheric $\mathrm{CO}_{2}$ increases gradually over decades to centuries. A recent modelling study has looked at the difference in ecosystem response those two scenarios may entail, by simulating the Duke and ORNL FACE experiments over a 300 year time period, with no consistent pattern detected (Walker et al. 2015). In the long run (>10 years), initial responses seen in step-change $\mathrm{CO}_{2}$ experiments are most likely mitigated due to compensatory effects (Leuzinger et al. 2011, Norby \& Zak 2011), although in the case of photosynthesis, this could not be confirmed in the FACE experiment on deciduous trees at the same site as the present study took place (Bader et al. 2010).

Our data indicate a strong $\mathrm{CO}_{2}$-driven stimulation of shoot photosynthesis under controlled leaf chamber conditions across cardinal directions in these tallest and oldest trees ever exposed to $e \mathrm{CO}_{2}$. There appeared no overall or daytime-dependent stimulation of $\mathrm{CO}_{2}$ release from stems or soil under FACE conditions suggesting that the extra $C$ assimilated during the initial study phase was not rapidly returned to the atmosphere via respiratory processes. This confirms earlier results from experiments at this and other sites that the carbon balance cannot easily be closed in mature forests that are exposed to elevated $\mathrm{CO}_{2}$ (Fatichi \& Leuzinger 2013). The most likely fate for the additional C are multiple sinks along its pathway that may be too small to track individually, given the limited statistical power of such large-scale experiments (Mildner et al. 2015).

\section{Acknowledgements}

The authors are indebted to Erwin Amstutz for crane operation and support during measurements campaigns. We thank Rolf Siegwolf from the Paul Scherrer Institute (Switzerland) for the provision of equipment. We would also like to thank four anonymous reviewers, whose valuable comments greatly helped to improve this manuscript. The SCC FACE study was supported by the Swiss National Science Foundation (grant 3100AO111914/1). 


\section{References}

Acosta, M., Pokorný, R., Janouš, D., Marek, M., 2010. Stem respiration of Norway spruce trees under elevated $\mathrm{CO}_{2}$ concentration. Biologia Plantarum 54, 773-776.

Amthor, J.S., 1984. The role of maintenance respiration in plant growth. Plant, Cell \& Environment 7, 561-569.

Atkin, O., Millar, A., Gardeström, P., Day, D., 2000. Photosynthesis, Carbohydrate Metabolism and Respiration in Leaves of Higher Plants, in: Leegood, R., Sharkey, T., von Caemmerer, S. (Eds.), Photosynthesis: Physiology and Metabolism. Kluwer Academic Publishers.

Bader, M.K.-F., Körner, C., 2010. No overall stimulation of soil respiration under mature deciduous forest trees after 7 years of $\mathrm{CO}_{2}$ enrichment. Global Change Biology 16, 28302843.

Bader, M.K.-F., Leuzinger, S., Keel, S.G., Siegwolf, R.T., Hagedorn, F., Schleppi, P., Körner, C., 2013. Central European hardwood trees in a high- $\mathrm{CO}_{2}$ future: synthesis of an 8-year forest canopy $\mathrm{CO}_{2}$ enrichment project. Journal of Ecology 101, 1509-1519.

Bader, M.K.-F., Siegwolf, R., Körner, C., 2010. Sustained enhancement of photosynthesis in mature deciduous forest trees after 8 years of free air $\mathrm{CO}_{2}$ enrichment. Planta 232, 11151125.

Bloemen, J., McGuire, M.A., Aubrey, D.P., Teskey, R.O., Steppe, K., 2013. Transport of rootrespired $\mathrm{CO}_{2}$ via the transpiration stream affects aboveground carbon assimilation and $\mathrm{CO}_{2}$ efflux in trees. New Phytologist 197, 555-565.

Bowman, W.P., Barbour, M.M., Turnbull, M.H., Tissue, D.T., Whitehead, D., Griffin, K.L., 2005. Sap flow rates and sapwood density are critical factors in within- and between-tree variation in $\mathrm{CO}_{2}$ efflux from stems of mature Dacrydium cupressinum trees. New Phytologist $167,815-828$.

Buchmann, N., 2000. Biotic and abiotic factors controlling soil respiration rates in Picea abies stands. Soil Biology and Biochemistry 32, 1625-1635.

Burnham, K.P., Anderson, D.R., 2002. Model selection and multimodel inference: a practical information-theoretic approach. Springer.

Butnor, J.R., Johnsen, K.H., Oren, R., Katul, G.G., 2003. Reduction of forest floor respiration by fertilization on both carbon dioxide-enriched and reference 17-year-old loblolly pine stands. Global Change Biology 9, 849-861.

Caprez, R., Niklaus, P., Körner, C., 2012. Forest soil respiration reflects plant productivity across a temperature gradient in the Alps. Oecologia 170, 1143-1154.

Carey, E.V., DeLucia, E.H., Ball, J.T., 1996. Stem maintenance and construction respiration in Pinus ponderosa grown in different concentrations of atmospheric $\mathrm{CO}_{2}$. Tree Physiology 16, 125-130. 
Cernusak, L.A., Hutley, L.B., Beringer, J., Tapper, N.J., 2006. Stem and leaf gas exchange and their responses to fire in a north Australian tropical savanna. Plant, Cell \& Environment 29, 632-646.

Covey-Crump, E., Attwood, R., Atkin, O., 2002. Regulation of root respiration in two species of Plantago that differ in relative growth rate: the effect of short- and long-term changes in temperature. Plant, Cell \& Environment 25, 1501-1513.

Crous, K.Y., Walters, M.B., Ellsworth, D.S., 2008. Elevated $\mathrm{CO}_{2}$ concentration affects leaf photosynthesis-nitrogen relationships in Pinus taeda over nine years in FACE. Tree Physiology 28, 607-614.

Damesin, C., Ceschia, E., Le Goff, N., Ottorini, J.-M., Dufrène, E., 2002. Stem and branch respiration of beech: from tree measurements to estimations at the stand level. New Phytologist 153, 159-172.

Dieleman, W.I.J., Vicca, S., Dijkstra, F.A., Hagedorn, F., Hovenden, M.J., Larsen, K.S., Morgan, J.A., Volder, A., Beier, C., Dukes, J.S., King, J., Leuzinger, S., Linder, S., Luo, Y., Oren, R., De Angelis, P., Tingey, D., Hoosbeek, M.R., Janssens, I.A., 2012. Simple additive effects are rare: a quantitative review of plant biomass and soil process responses to combined manipulations of $\mathrm{CO}_{2}$ and temperature. Global Change Biology 18, 2681-2693.

Edwards, N.T., Tschaplinski, T.J., Norby, R.J., 2002. Stem respiration increases in $\mathrm{CO}_{2}-$ enriched sweetgum trees. New Phytologist 155, 239-248.

Ellsworth, D.S., Thomas, R., Crous, K.Y., Palmroth, S., Ward, E., Maier, C., DeLucia, E., Oren, R., 2012. Elevated $\mathrm{CO}_{2}$ affects photosynthetic responses in canopy pine and subcanopy deciduous trees over 10 years: a synthesis from Duke FACE. Global Change Biology 18, 223242.

Epron, D., Ngao, J., Dannoura, M., Bakker, M., Zeller, B., Bazot, S., Bosc, A., Plain, C., Lata, J., Priault, P., 2011. Seasonal variations of belowground carbon transfer assessed by in situ ${ }^{13} \mathrm{CO}_{2}$ pulse labelling of trees. Biogeosciences 8, 1153-1168.

Etzold, S., Zweifel, R., Ruehr, N.K., Eugster, W., Buchmann, N., 2013. Long-term stem $\mathrm{CO}_{2}$ concentration measurements in Norway spruce in relation to biotic and abiotic factors. New Phytologist 197, 1173-1184.

Fatichi, S., Leuzinger, S., 2013. Reconciling observations with modeling: the fate of water and carbon allocation in a mature deciduous forest exposed to elevated $\mathrm{CO}_{2}$. Agricultural and Forest Meteorology 174, 144-157.

Gielen, B., Scarascia-Mugnozza, G., Ceulemans, R., 2003. Stem respiration of Populus species in the third year of free-air $\mathrm{CO}_{2}$ enrichment. Physiologia plantarum 117, 500-507.

Greenep, H., Turnbull, M.H., Whitehead, D., 2003. Response fo photosynthesis in secondgeneration Pinus radiata trees to long-term exposure to elevated carbon dioxid partial pressure. Tree Physiology 23, 569-576. 
Griffin, K.L., Anderson, R.O., Tissue, D.T., Turnbull, M.H., Whitehead, D., 2004. Variations in dark respiration and mitochondrial numbers within needles of Pinus radiata grown in ambient or elevated $\mathrm{CO}_{2}$ partial pressure. Tree Physiology 24, 347-353.

Hamilton, J.G., DeLucia, E.H., George, K., Naidu, S.L., Finzi, A.C., Schlesinger, W.H., 2002. Forest carbon balance under elevated $\mathrm{CO}_{2}$. Oecologia 131, 250-260.

Högberg, P., Nordgren, A., Buchmann, N., Taylor, A.F.S., Ekblad, A., Hogberg, M.N., Nyberg, G., Ottosson-Lofvenius, M., Read, D.J., 2001. Large-scale forest girdling shows that current photosynthesis drives soil respiration. Nature 411, 789-792.

Jackson, R.B., Cook, C.W., Pippen, J.S., Palmer, S.M., 2009. Increased belowground biomass and soil $\mathrm{CO}_{2}$ fluxes after a decade of carbon dioxide enrichment in a warm-temperate forest. Ecology 90, 3352-3366.

Janssens, I.A., Lankreijer, H., Matteucci, G., Kowalski, A.S., Buchmann, N., Epron, D., Pilegaard, K., Kutsch, W., Longdoz, B., Grünwald, T., Montagnani, L., Dore, S., Rebmann, C., Moors, E.J., Grelle, A., Rannik, Ü., Morgenstern, K., Oltchev, S., Clement, R., Guðmundsson, J., Minerbi, S., Berbigier, P., Ibrom, A., Moncrieff, J., Aubinet, M., Bernhofer, C., Jensen, N.O., Vesala, T., Granier, A., Schulze, E.D., Lindroth, A., Dolman, A.J., Jarvis, P.G., Ceulemans, R., Valentini, R., 2001. Productivity overshadows temperature in determining soil and ecosystem respiration across European forests. Global Change Biology 7, 269-278.

King, J.S., Hanson, P.J., Bernhardt, E., DeAngelis, P., Norby, R.J., Pregitzer, K.S., 2004. A multiyear synthesis of soil respiration responses to elevated atmospheric $\mathrm{CO}_{2}$ from four forest FACE experiments. Global Change Biology 10, 1027-1042.

Körner, C., 2006. Plant $\mathrm{CO}_{2}$ responses: an issue of definition, time and resource supply. New Phytologist 172, 393-411.

Kuzyakov, Y., Cheng, W., 2001. Photosynthesis controls of rhizosphere respiration and organic matter decomposition. Soil Biology and Biochemistry 33, 1915-1925.

Kuzyakov, Y., Gavrichkova, O., 2010. REVIEW: Time lag between photosynthesis and carbon dioxide efflux from soil: a review of mechanisms and controls. Global Change Biology 16, 3386-3406.

Leuzinger, S., Bader, M.K.-F., 2012. Experimental vs. modeled water use in mature Norway spruce (Picea abies) exposed to elevated $\mathrm{CO}_{2}$. Frontiers in plant science 3 .

Leuzinger, S., Luo, Y., Beier, C., Dieleman, W., Vicca, S., Körner, C., 2011. Do global change experiments overestimate impacts on terrestrial ecosystems? Trends in Ecology and Evolution 26, 236-241.

Levy, P., Meir, P., Allen, S., Jarvis, P., 1999. The effect of aqueous transport of $\mathrm{CO}_{2}$ in xylem sap on gas exchange in woody plants. Tree Physiology 19, 53-58.

Malhi, Y., Baldocchi, D., Jarvis, P., 1999. The carbon balance of tropical, temperate and boreal forests. Plant, Cell \& Environment 22, 715-740. 
Mildner, M., Bader, M.K.-F., Baumann, C., Körner, C., 2015. Respiratory fluxes and fine root responses in mature Picea abies trees exposed to elevated atmospheric $\mathrm{CO}_{2}$ concentrations. Biogeochemistry 124, 95-111.

Mildner, M., Bader, M.K.-F., Leuzinger, S., Siegwolf, R.T., Körner, C., 2014. Long-term ${ }^{13} \mathrm{C}$ labeling provides evidence for temporal and spatial carbon allocation patterns in mature Picea abies. Oecologia, 1-16.

Moore, D.J., Gonzalez-Meler, M.A., Taneva, L., Pippen, J.S., Kim, H.-S., DeLucia, E.H., 2008. The effect of carbon dioxide enrichment on apparent stem respiration from Pinus taeda $\mathrm{L}$. is confounded by high levels of soil carbon dioxide. Oecologia 158, 1-10.

Norby, R.J., Zak, D.R., 2011. Ecological lessons from free-air $\mathrm{CO}_{2}$ enrichment (FACE) experiments. Annual Review of Ecology, Evolution, and Systematics 42, 181.

Nowak, R.S., Ellsworth, D.S., Smith, S.D., 2004. Functional responses of plants to elevated atmospheric $\mathrm{CO}_{2}$ - do photosynthetic and productivity data from FACE experiments support early predictions? New Phytologist 162, 253-280.

Pepin, S., Körner, C., 2002. Web-FACE: a new canpy free-air $\mathrm{CO}_{2}$ enrichment system for tall trees in mature forests. Oecologia 133, 1-9.

Pinheiro, J., Bates, D., DebRoy, S., Sarkar, D., R Core Team, 2014. nlme: Linear and Nonlinear Mixed Effects Models, R package version 3.1-118 ed.

R Development Core Team, 2014. R: A language and environment for statistical computing. R Foundation for Statistical Computing, Vienna, Austria.

Raich, J., Nadelhoffer, K., 1989. Belowground carbon allocation in forest ecosystems: global trends. Ecology 70, 1346-1354.

Roy, J., Mooney, H.A., Saugier, B., 2001. Terrestrial global productivity. Academic Press, San Diego.

Ryan, M.G., Gower, S.T., Hubbard, R.M., Waring, R.H., Gholz, H.L., Cropper Jr, W.P., Running, S.W., 1995. Woody tissue maintenance respiration of four conifers in contrasting climates. Oecologia 101, 133-140.

Ryan, M.G., Hubbard, R.M., Clark, D.A., Sanford Jr, R.L., 1994. Woody-tissue respiration for Simarouba amara and Minquartia guianensis, two tropical wet forest trees with different growth habits. Oecologia 100, 213-220.

Sigurdsson, B., Medhurst, J., Wallin, G., Eggertson, O., Linder, S., 2013. Growth of mature boreal Norway spruce was not affected by elevated $\mathrm{CO}_{2}$ and/or air temperature unless nutrient availability was improved. Tree Physiology 33, 1192-1205.

Sigurdsson, B., Roberntz, P., Freeman, M., Naess, M., Saxe, H., Thorgeirsson, H., Linder, S., 2002. Impact studies on Nordic forests: effects of elevated $\mathrm{CO}_{2}$ and fertilization on gas exchange. Canadian Journal of Forest Research 32, 779-788.

Tang, J., Baldocchi, D.D., Xu, L., 2005. Tree photosynthesis modulates soil respiration on a diurnal time scale. Global Change Biology 11, 1298-1304. 
Teskey, R., McGuire, M., 2002. Carbon dioxide transport in xylem causes errors in estimation of rates of respiration in stems and branches of trees. Plant, Cell \& Environment 25, 15711577.

Teskey, R., McGuire, M., 2007. Measurement of stem respiration of sycamore (Platanus occidentalis L.) trees involves internal and external fluxes of $\mathrm{CO}_{2}$ and possible transport of $\mathrm{CO}_{2}$ from roots. Plant, Cell \& Environment 30, 570-579.

Teskey, R.O., McGuire, M.A., 2005. $\mathrm{CO}_{2}$ transported in xylem sap affects $\mathrm{CO}_{2}$ efflux from Liquidambar styraciflua and Platanus occidentalis stems, and contributes to observed wound respiration phenomena. Trees 19, 357-362.

Thimonier, A., Graf Pannatier, E., Schmitt, M., Waldner, P., Lorenz, W., Schleppi, P., Dobbertin, M., Kräuchi, N., 2010. Does exceeding the critical loads for nitrogen alter nitrate leaching, the nutrient status of trees and their crown condition at Swiss Long-term Forest Ecosystem Research (LWF) sites? European Journal of Forest Research 129, 443-461.

Walker, A.P., Zaehle, S., Medlyn, B.E., De Kauwe, M.G., Asao, S., Hickler T. ,Parton, W., Ricciuto, D.M., Wang Y.-P., Warlind, D. Norby, R.J., 2015. Predicting long-term carbon sequestration in response to $\mathrm{CO}_{2}$ enrichment: how and why do current ecosystem models differ? Global Biogeochemical Cycles 29, 476-495.

Warren, J.M., Jensen, A.M., Medlyn, B.E., Norby, R.J., Tissue, D.T., 2014. $\mathrm{CO}_{2}$ stimulation of photosynthesis in Liquidambar styraciflua is not sustained during a 12-year field experiment. AoB Plants.

Wertin, T.M., Teskey, R.O., 2008. Close coupling of whole-plant respiration to net photosynthesis and carbohydrates. Tree Physiology 28, 1831-1840.

Wofsy, S., Goulden, M., Munger, J., Fan, S.-M., Bakwin, P., Daube, B., Bassow, S., Bazzaz, F., 1993. Net exchange of $\mathrm{CO}_{2}$ in a mid-latitude forest. Science 260, 1314-1317.

Wood, S.N., 2011. Fast stable restricted maximum likelihood and marginal likelihood estimation of semiparametric generalized linear models. Journal of the Royal Statistical Society: Series B (Statistical Methodology) 73, 3-36.

Zha, T.-S., Kellomäki, S., Wang, K.-Y., Ryyppö, A., 2005. Respiratory responses of Scots pine stems to 5 years of exposure to elevated $\mathrm{CO}_{2}$ concentration and temperature. Tree Physiology 25, 49-56.

Zuur, A., leno, E.N., Walker, N., Saveliev, A.A., Smith, G.M., 2009. Mixed effects models and extensions in ecology with R. Springer.

\section{Figure captions}


Figure 1 (a) Net photosynthetic rate and (b) stomatal conductance (lower panel) of one-year old (2008) south-facing branchlets of Picea abies as a function of time after detachment. The dashed lines indicate the mean values before branchlet removal. The solid lines show the mean of five branchlets derived from different adult spruce trees \pm 1 standard error (grey area). Measurements were conducted in logging mode over a period of 230 minutes using a 1-minute interval under saturating light intensity of $1500 \mu \mathrm{mol} \mathrm{m} \mathrm{m}^{-2} \mathrm{~s}^{-1}, 25^{\circ} \mathrm{C}$ leaf temperature, and an ALVPD (air-to-leaf vapour pressure deficit) of ca. $1.1 \mathrm{kPa}$. For the sake of clarity the regression line for the linear decline in the photosynthetic rate was omitted and only the linear regression equation is shown.

Figure 2 Instantaneous enhancement of light-saturated photosynthesis (PER) measured across cardinal directions in upper-crown branchlets of mature Picea abies trees. Measurements were conducted on previous-year and current-year shoot sections one week before the onset of canopy $\mathrm{CO}_{2}$-enrichment (upper panel) and one week afterwards (lower panel) at the SCC FACE site. Means $\pm \mathrm{SE}, n=5$.

Figure 3 Maximum rate of Rubisco carboxylation $\left(V_{c \max }\right)$ and maximum electron transport rate $\left(J_{\max }\right)$ in south-facing upper-crown branchlets of mature Picea abies trees. Measurements were conducted on previous-year and current-year shoot sections one week before the onset of canopy $\mathrm{CO}_{2}$-enrichment (upper panel) and one week afterwards (lower panel) at the SCC FACE site. Means $\pm \mathrm{SE}, n=5$. ${ }^{* * *} P<0.001$ (likelihood ratio test, see material and methods).

Figure $4(\mathbf{a}-\mathbf{b})$ Diurnal courses of net photosynthesis $\left(A_{\text {net }}\right)$ in previous- and current-year needles, (c) stem $\mathrm{CO}_{2}$ efflux $\left(C E_{\text {stem }}\right)$ and bark temperature ( $\left.\mathrm{T}_{\text {bark }}\right)$, and (d) soil respiration $\left(R_{\text {soil }}\right)$ along with soil temperature at $10 \mathrm{~cm}$ depth $\left(\mathrm{T}_{\text {soil }}\right)$. The measurement campaigns were performed at the Swiss Canopy Crane FACE site on or under $\mathrm{CO}_{2}$-enriched (closed symbols, solid lines) and control trees (open symbols, dashed lines). Means $\pm \mathrm{SE}, n=5$. Black and white bars on top indicate night- and daytime hours. Lines represent fits from generalised additive mixed models applied to the non-aggregated data.

Figures

Fig. 1 


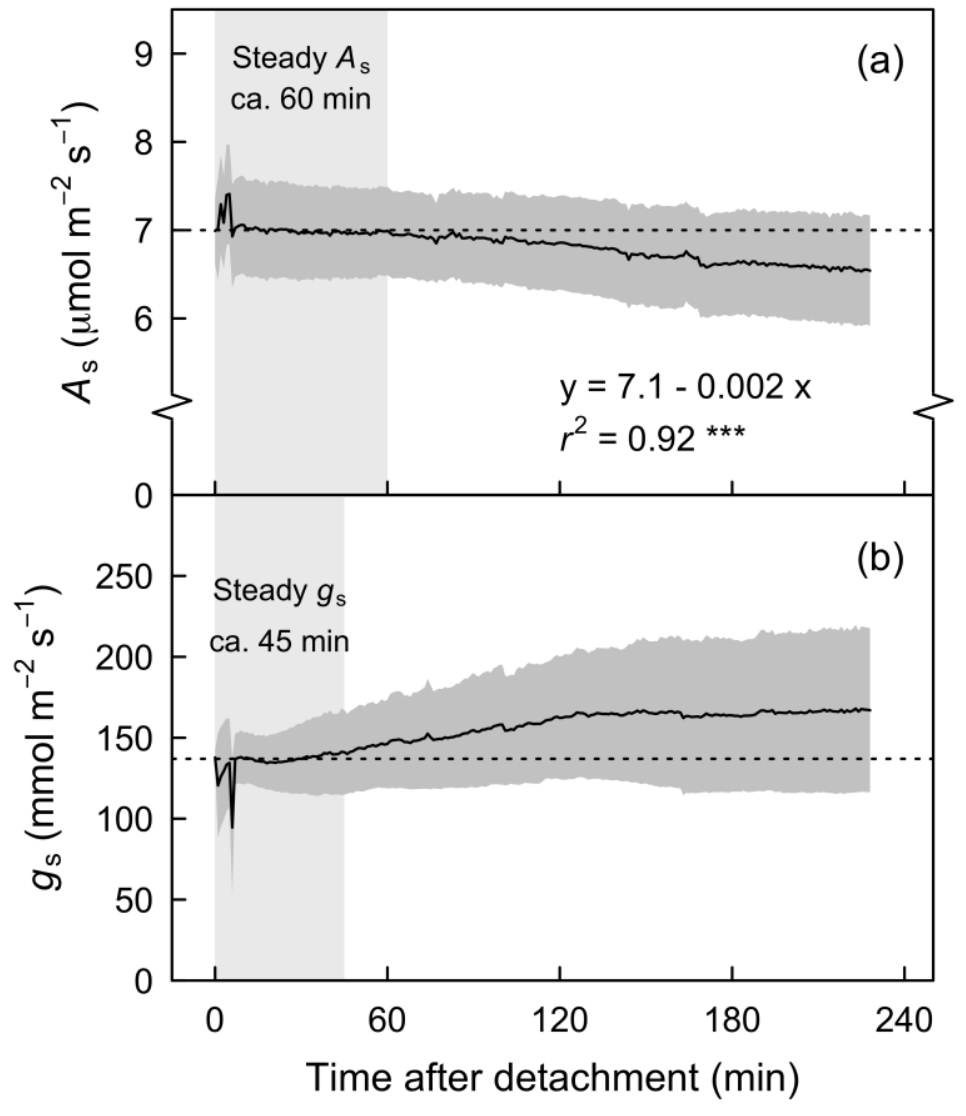


Fig. 2
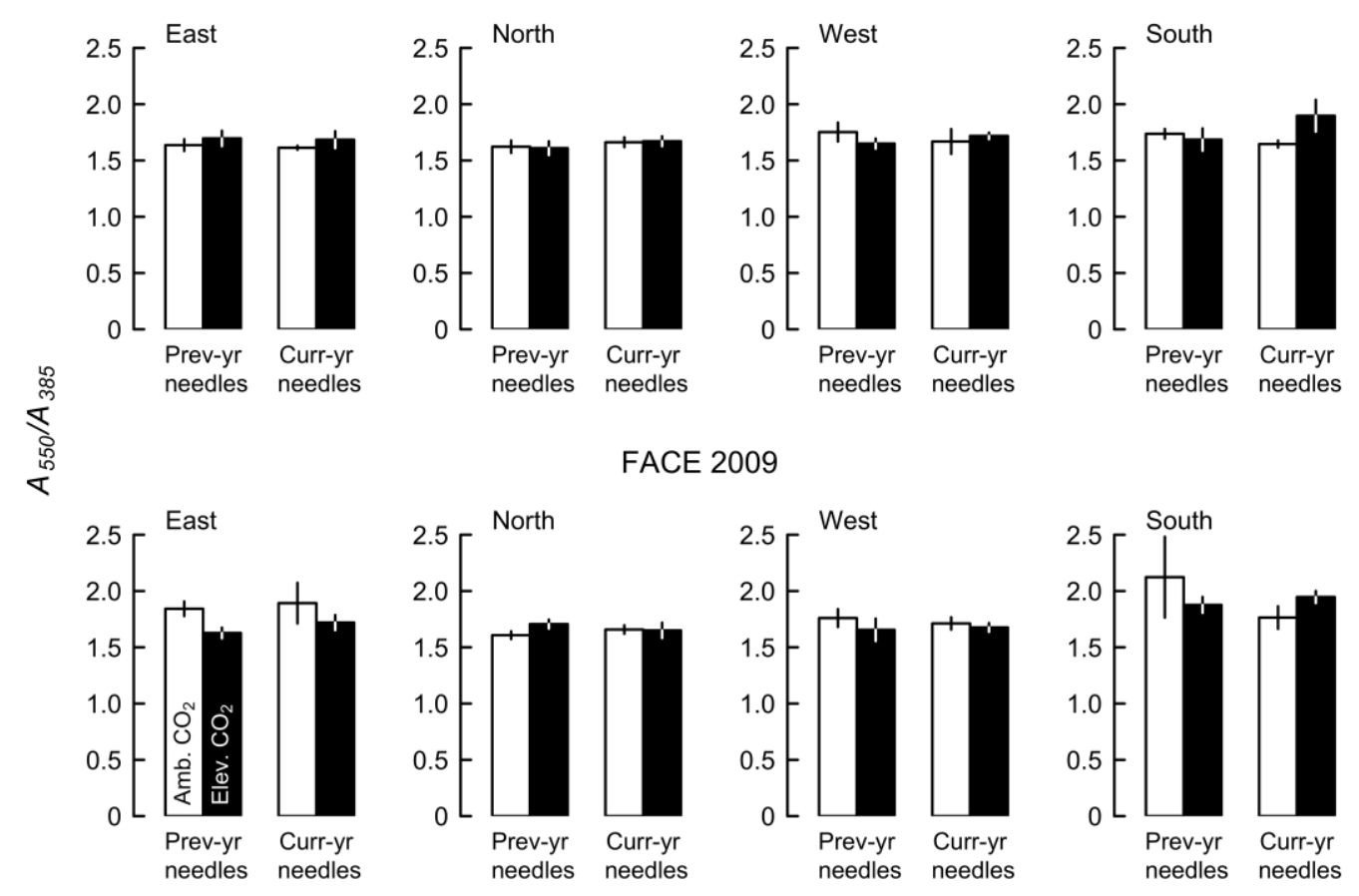

Fig. 3 

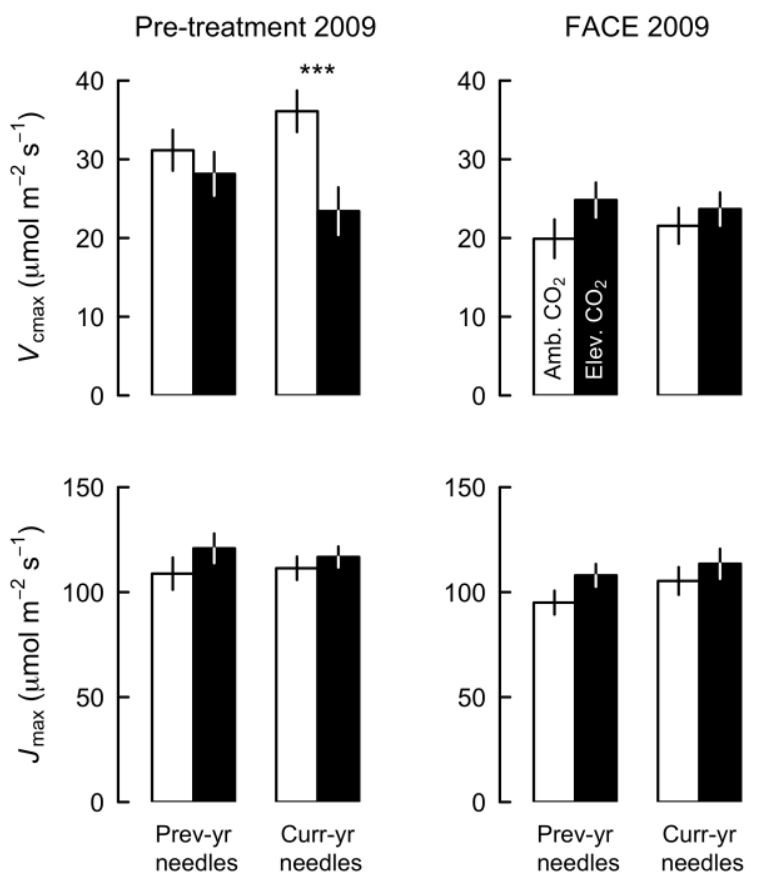
Fig. 4

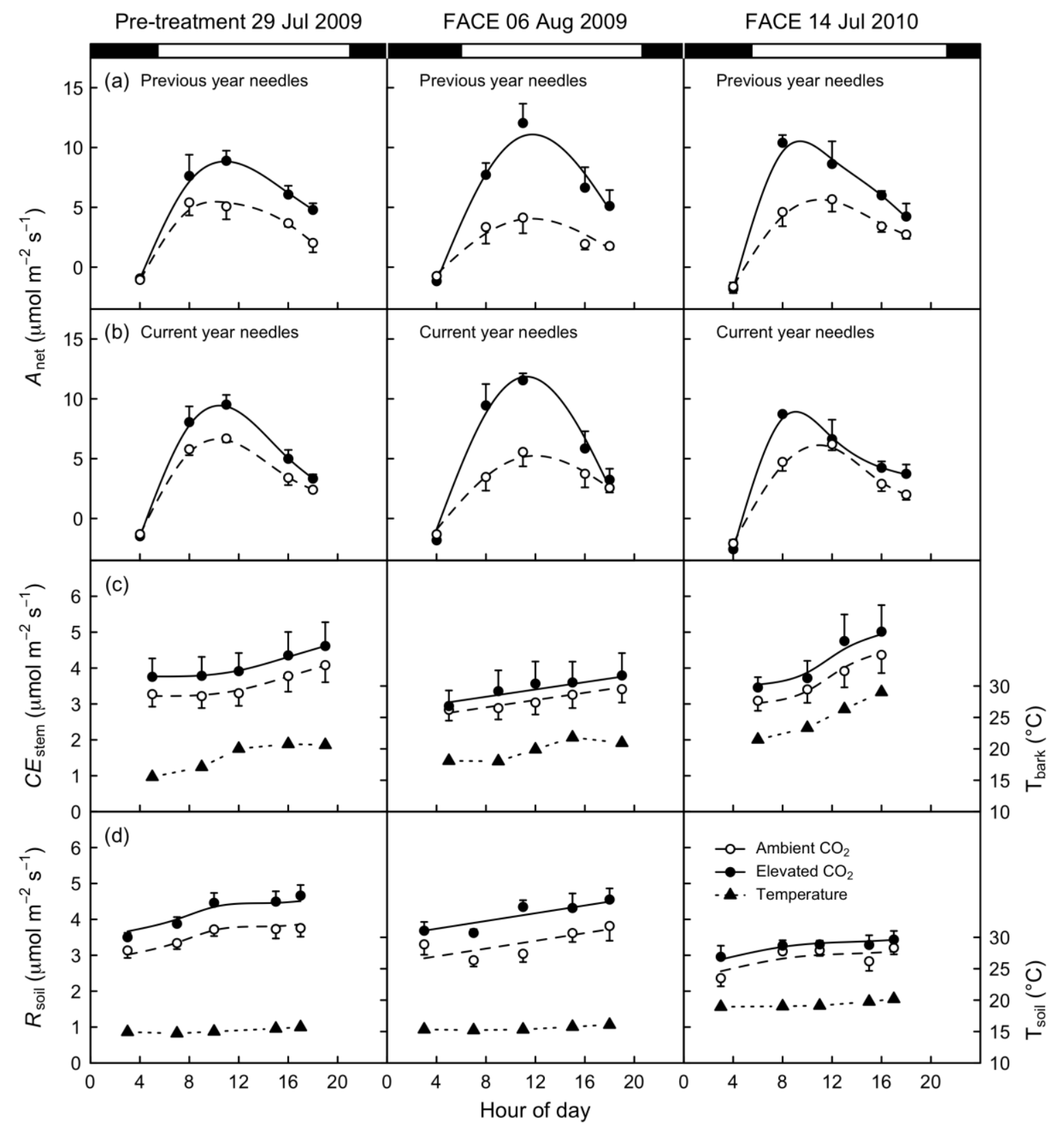




\section{Table headers}

Table 1 Results from a generalised least squares model for diurnal gas-exchange of Picea abies needles applying individual smoothers for $a \mathrm{CO}_{2}$ and $e \mathrm{CO}_{2} . \mathrm{CO}_{2}$ treatment $=a \mathrm{CO}_{2} \mathrm{vs}$. $e \mathrm{CO}_{2}$, needle age = previous-year vs. current-year needles, FACE $2009=6$ Aug 2009 one week after the start of $\mathrm{CO}_{2}$ enrichment, FACE $2010=14 \mathrm{Jul} 2010$, one year after the start of $\mathrm{CO}_{2}$ enrichment (the pre-treatment recording is included as baseline in the intercept term). $e d f=$ estimated degrees of freedom, $\mathrm{s}=$ smoother term.

Table 2 Results from a generalised additive mixed model for diurnal gas-exchange of Picea abies needles applying individual smoothers for $a \mathrm{CO}_{2}$ and $e \mathrm{CO}_{2} . \mathrm{CO}_{2}$ treatment $=a \mathrm{CO}_{2}$ vs. $e \mathrm{CO}_{2}$, needle age $=$ previous-year vs. current-year needles, FACE $2009=6$ Aug 2009 one week after the start of $\mathrm{CO}_{2}$ enrichment, FACE $2010=14 \mathrm{Jul} 2010$, one year after the start of $\mathrm{CO}_{2}$ enrichment (the pre-treatment recording is included as baseline in the intercept term). $e d f=$ estimated degrees of freedom, $\mathrm{s}=$ smoother term.

Table 3 Results from a generalised additive mixed model for diurnal $C$ release from Picea abies stems. $\mathrm{CO}_{2}$ treatment $=a \mathrm{CO}_{2}$ vs. $e \mathrm{CO}_{2}$, Diurnal FACE $2009=$ recording of 6 Aug 2009 one week after the start of $\mathrm{CO}_{2}$ enrichment, Diurnal FACE $2010=$ recording of $14 \mathrm{Jul} 2010$, one year after the start of $\mathrm{CO}_{2}$ enrichment (the pre-treatment recording is included as baseline in the intercept term). edf = estimated degrees of freedom, $\mathrm{s}=$ smoother term.

Table 4 Results from a generalised additive mixed model for diurnal soil respiration under Picea abies trees. $\mathrm{CO}_{2}$ treatment $=a \mathrm{CO}_{2}$ vs. eCO , Diurnal FACE $2009=$ recording of 6 Aug 2009 one week after the start of $\mathrm{CO}_{2}$ enrichment, Diurnal FACE $2010=$ recording of $14 \mathrm{Jul}$ 2010 , one year after the start of $\mathrm{CO}_{2}$ enrichment (the pre-treatment recording is included as baseline in the intercept term). edf = estimated degrees of freedom, $\mathrm{s}=$ smoother term. 
Table 1

\begin{tabular}{|c|c|c|c|c|}
\hline Parameter & $D F_{n u m}$ & $D F_{d e n}$ & $F$ & $P$ \\
\hline \multicolumn{5}{|l|}{ Pre-treatment } \\
\hline Intercept & 1 & 64 & 11429.77 & $<0.001 * * *$ \\
\hline Cardinal direction & 3 & 64 & 0.82 & 0.486 \\
\hline Needle age & 1 & 64 & 0.05 & 0.825 \\
\hline $\mathrm{CO}_{2}$ & 1 & 64 & 0.47 & 0.494 \\
\hline Cardinal direction $\times$ needle age & 3 & 64 & 0.31 & 0.821 \\
\hline Cardinal direction $\times \mathrm{CO}_{2}$ & 3 & 64 & 0.421 & 0.739 \\
\hline Needle age $\times \mathrm{CO}_{2}$ & 1 & 64 & 1.71 & 0.196 \\
\hline Cardinal direction $\times$ needle age $\times \mathrm{CO}_{2}$ & 3 & 64 & 0.80 & 0.499 \\
\hline \multicolumn{5}{|l|}{ FACE } \\
\hline Intercept & 1 & 61 & 8886.20 & $<0.001 * * *$ \\
\hline Cardinal direction & 3 & 61 & 2.47 & 0.070 \\
\hline Needle age & 1 & 61 & 0.18 & 0.673 \\
\hline $\mathrm{CO}_{2}$ & 1 & 61 & 0.49 & 0.487 \\
\hline Cardinal direction $\times$ needle age & 3 & 61 & 0.81 & 0.494 \\
\hline Cardinal direction $\times \mathrm{CO}_{2}$ & 3 & 61 & 1.69 & 0.178 \\
\hline Needle age $\times \mathrm{CO}_{2}$ & 1 & 61 & 0.01 & 0.943 \\
\hline Cardinal direction $\times$ needle age $\times \mathrm{CO}_{2}$ & 3 & 61 & 0.85 & 0.473 \\
\hline
\end{tabular}


Table 2

\begin{tabular}{lccc}
\hline $\begin{array}{l}\text { Parametric } \\
\text { coefficients }\end{array}$ & Estimate (SE) & \multicolumn{1}{l}{$t$} & $P$ \\
\hline Intercept & $3.25(0.23)$ & 13.87 & $<0.001^{* * *}$ \\
$\mathrm{CO}_{2}$ treatment & $2.07(0.33)$ & 6.35 & $<0.001^{* * *}$ \\
Needle age & $-0.36(0.10)$ & -3.59 & $<0.001 * * *$ \\
Diurnal FACE 2009 & $-0.02(0.20)$ & -0.12 & 0.91 \\
Diurnal FACE 2010 & $-0.63(0.20)$ & -3.18 & $<0.01 * *$
\end{tabular}

Approx. significance of smooth terms

\begin{tabular}{rrcc} 
edf & $F$ & $P$ \\
s(time of day) : $\mathrm{CO}_{2}$ & 2.93 & 153.9 & $<0.001 * * *$ \\
\hline
\end{tabular}

Table 3

\begin{tabular}{lccc}
\hline $\begin{array}{l}\text { Parametric } \\
\text { coefficients }\end{array}$ & Estimate (SE) & $t$ & $P$ \\
\hline Intercept & $3.10(0.35)$ & 8.91 & $<0.001 * * *$ \\
$\mathrm{CO}_{2}$ treatment & $0.45(0.35)$ & 1.29 & 0.20 \\
Diurnal FACE 2009 & $0.55(0.44)$ & 1.29 & 0.20 \\
Diurnal FACE 2010 & $0.55(0.43)$ & 1.29 & 0.20
\end{tabular}

Approx. significance of smooth terms

\begin{tabular}{lrrc} 
& $e d f$ & $F$ & $P$ \\
s(time of day) & 1.00 & 32.65 & $<0.001 * * *$ \\
s(bark temperature) & 2.73 & 6.58 & $<0.001 * * *$ \\
\hline
\end{tabular}


Table 4

\begin{tabular}{lccc}
\hline $\begin{array}{l}\text { Parametric } \\
\text { coefficients }\end{array}$ & Estimate (SE) & \multicolumn{1}{l}{$t$} & $P$ \\
\hline Intercept & $3.58(0.14)$ & 26.00 & $<0.001 * * *$ \\
$\mathrm{CO}_{2}$ treatment & $0.58(0.14)$ & 4.21 & $<0.001 * * *$ \\
Diurnal FACE 2009 & $-0.14(0.17)$ & -0.83 & 0.41 \\
Diurnal FACE 2010 & $-0.79(0.17)$ & -4.71 & $<0.001 * * *$
\end{tabular}

Approx. significance of smooth terms

\begin{tabular}{cccc} 
& $e d f$ & $F$ & $P$ \\
s(time of day) & 1.00 & 41.85 & $<0.001 * * *$ \\
\hline
\end{tabular}

